\title{
O jovem, lócus teológico da esperança cristã, no pontificado do Papa Francisco
}

\author{
The young, theological locus of Christian hope, in the \\ pontificate of Pope Francis
}

Gislene Danielski

\section{Resumo}

Com este artigo faremos uma breve reflexão acerca da esperança cristã e as juventudes. Tomaremos como ponto de partida o Concilio Vaticano II e suas manifestações diretas e indiretas em torno da temática, buscando sua continuidade no pontificado do Papa Francisco. Veremos que o tema é amplamente abordado pelo Concílio, mesmo que esse não tenha destinado nenhum documento ou capítulo em referência direta aos jovens, o que não significou que os tenha deixado à margem de suas reflexões e preocupações. Encontraremos nos documentos conciliares inúmeras citações que evidenciam os jovens como esperança da Igreja e ao mesmo tempo destinatários da Esperança Cristã, necessitados de testemunhos autênticos que semeiem a fé em seus corações. Referindo-se a Francisco, poderemos perceber que, desde o início de seu pontificado, sua esperança nas juventudes é evidente. Em seus discursos insiste na temática e atualmente faz com o que os olhares de toda a Igreja se voltem para as juventudes uma vez que propõe ao Sínodo 2018 o tema: Juventudes, fé e discernimento vocacional.

Palavras-chave: Concílio Vaticano II. Papa Francisco. Igreja. Esperança Cristã. Juventudes.

\begin{abstract}
With this article we will make a brief reflection on Christian hope and the youths. We will take as a starting point the second Vatican Council and its direct and indirect manifestations around the theme, seeking its continuity in
\end{abstract}


the pontificate of Pope Francis. We will see that the theme is vastly addressed by the council, even though it has not sent any document or chapter in direct reference to young people, which does not mean it has left them outside their reflections and preoccupations. We will find in the conciliar documents countless quotations that show young people as hope of the church and at the same time the recipients of the Christian Hope, in need of authentic witnesses who sow faith in their hearts. With reference to Francis, we can see that, from the beginning of his pontificate, his hope in youth is evident. In his speech, he insists on the thematic and currently causes the eyes of the whole church to turn to youth as it proposes to the 2018 synod the theme: Youth, faith and vocational discernment.

Keywords: Second Vatican Council. Pope Francis. Church. Christian Hope. Youths.

\section{Introdução}

De acordo com $\mathrm{H}$. Gonçalves ${ }^{1}$ o interesse social por assuntos relacionados às juventudes ${ }^{2}$ é cíclico, e está geralmente associado a situações caracterizadas por crises e conflitos. P. Singer nos dirá que se trata de um enfoque recorrentemente negativo que desponta de tempos em tempos e não tem propriamente os jovens como centro de seus interesses. As crises e os excessos, os conflitos e as explosões que a eles se seguem acompanham a história da preocupação social e acadêmica com as juventudes. ${ }^{3}$ A construção social em torno dos jovens é carregada de significados negativos, prevalecendo o rótulo de geradores de problemas que se refletem em seu cotidiano e nas instituições das quais participam. Todos esses conceitos de culpabilização e condenação nos mostram que os jovens são de fato foco de interesse social e

\footnotetext{
${ }^{1}$ GONÇALVES, H. S., Juventude brasileira, entre a tradição e a modernidade, p. 207-219.

2 Diante da história da construção do termo "juventude", hoje somos convidados a não nos determos na juventude apenas como uma categoria hegemônica que se presta a representar todos os jovens. Assumimos a reflexão de que: “[...] precisamos falar de juventudes, no plural, e não de juventude, no singular, para não esquecer as diferenças e desigualdades que atravessam esta condição. Esta mudança de alerta revela uma transformação importante na própria noção social: a juventude, mesmo que não explicitamente, é reconhecida como condição válida, que faz sentido, para todos os grupos sociais, embora apoiada sobre situações e significações diferentes". ABRAMO, H. W., Retratos juvenis, p. 44.

${ }^{3}$ SINGER, P., A juventude como coorte, p. 27-35.
} 
acadêmico quando considerados um problema a ser compreendido e até mesmo sanado. ${ }^{4}$

Mesmo inserida nessa realidade social a Igreja é convocada a portar-se de maneira diferente diante dos jovens, a lançar sobre eles o olhar do acolhimento e não do mero interesse como fazem muitas instâncias sociais. A Igreja vê nos jovens um símbolo de si mesma, ${ }^{5}$ e é assim por vocação. Os vê como esperança não por simples interesse de perpetuação, mas por ser o jovem lugar teológico ${ }^{6}$ de encontro com Cristo e também espaço de ação do Espírito Santo que continua fazendo novas todas as coisas. ${ }^{7}$ É nessa ótica que vemos a atuação do Concílio Vaticano II no relacionamento da Igreja junto aos jovens, isto é, estamos em um tempo em que a Igreja povo de Deus, formada por um grande número de jovens, sejam esses inseridos ou não na comunidade eclesial, é chamada a viver sua missão junto a toda humanidade, fazendo a experiência do encontro com Cristo e o testemunhando entre todas as nações. Assim, a Igreja caminha com os jovens, pois esses são a Igreja de Jesus Cristo, são também povo de Deus peregrino, objeto e sujeito de evangelização, para isso é necessário que a própria Igreja saiba transmitir às novas gerações as razões de viver e esperar. ${ }^{8} \mathrm{Na}$ carta endereçada aos jovens na conclusão do Concílio, Paulo VI declara a esperança que Igreja deposita nos jovens, tendo-os como possibilidade de futuro para a evangelização:

É finalmente a vós, rapazes e moças de todo o mundo, que o Concílio quer dirigir a sua última mensagem - pois sereis vós a recolher o facho das mãos dos vossos antepassados e a viver no mundo no momento das mais gigantescas transformações da sua história, sois vós quem, recolhendo o melhor do exemplo e do ensinamento dos vossos pais e mestres, ides constituir a sociedade de amanhã: salvar-vos-eis ou perecereis com ela. ${ }^{9}$

Também a afirmação da conferência episcopal de Puebla, ocorrida em 1979, que alega serem os jovens opção preferencial da Igreja,${ }^{10}$ reforça-nos a convicção de que nas novas gerações estão depositadas as esperanças da Igreja

\footnotetext{
${ }^{4}$ ESTEVES, L. C. G.; ABRAMOVAY, M., Juventude, juventudes, p. 28-30.

${ }^{5}$ PAULO VI, PP., Mensagem aos jovens na conclusão do Concílio Vaticano II.

${ }^{6}$ CELAM, Doc. 173, 357.

${ }^{7}$ Ap 21,6.

${ }^{8}$ GS 31.

${ }^{9}$ PAULO VI, PP., Mensagem aos jovens na conclusão do Concílio Vaticano II.

${ }^{10}$ DP 1186.
} 
e é esta Mãe que a elas oferece a Esperança plena, Jesus Cristo. Passadas 53 anos da conclusão do Concílio, vemos que os jovens continuam na pauta das preocupações eclesiais. Estamos às vésperas da XV Assembleia Geral Ordinária do Sínodo dos Bispos, que acontecerá entre os dias 03 a 28 de outubro de 2018, com o tema: "Os jovens, a fé e o discernimento vocacional". Por esta razão, este artigo apresenta alguns aspectos do pontificado do Papa Francisco acerca das juventudes que nos permitem compreender que os jovens continuam ocupando significativo espaço nas preocupações eclesiais. A Igreja vê nos jovens um lugar teológico da esperança, e além de reconhecê-los desta maneira, os compreende necessitados da esperança que o cristianismo gratuitamente oferece a todos, que é o Cristo, permitindo que o projeto do Reino se realize em toda a humanidade. Francisco demonstra prioridade ao tema da Esperança Cristã junto às juventudes. Seus pronunciamentos vêm repletos do assunto e o Sínodo aponta de maneira específica para o presente e o futuro das novas gerações quando trata da fé e do discernimento como temas centrais das atuais discussões eclesiais.

Façamos esse percurso eclesiológico, percebendo o valor da esperança cristã junto às juventudes, expresso no Concílio Vaticano II e no pontificado do Papa Francisco.

\section{O jovem na ótica do Concílio Vaticano II}

Sabemos que o Concílio Vaticano II se caracterizou pela abertura e olhar de reconciliação para com o mundo em suas complexas realidades. João XXIII o denominou como um "sopro de inesperada primavera". ${ }^{11}$ O Concílio buscou "um papel mais positivo e participativo da fé católica na sociedade" dessa perspectiva de abertura do Concílio à realidade social podemos entender que os jovens compunham o cenário das preocupações conciliares, uma vez que esses eram parte integrante da sociedade e de suas urgências. Dizemos ainda que, de maneira primordial, os jovens fizeram parte das preocupações conciliares, por serem esses filhos amados de Deus, necessitados de cuidados, necessitados da salvação doada por Jesus Cristo, e a Igreja tem a missão de levar adiante esse dom até o final dos tempos. A Igreja conciliar levou para suas pautas a realidade de tantos jovens que por diversas razões afastavam-se da religião, bem como se preocupou com os conflitos geracionais existentes, não deixando de reconhecer que esses jovens também eram capazes de assumir a fé

${ }^{11}$ BINGEMER, M. C. L., Vaticano II uma referência do nosso tempo.

${ }^{12}$ BINGEMER, M. C. L., El concilio y la emergência del laicado, p. 408. 
de maneira mais pura do que outros que já os haviam precedido. ${ }^{13}$ Diante da realidade das novas gerações a Igreja permaneceu crendo no futuro que essas podiam construir para toda humanidade.

Paulo VI assim como João XXIII, afirmou o desejo conciliar de fazer valer a misericórdia diante da sociedade e de seus sofrimentos. ${ }^{14}$ Por isso, entendemos que seu olhar aos jovens fora de cuidado e preocupação com o presente e o futuro de cada um, com suas possibilidades de salvação ou perdição em meio à realidade em que estavam inseridos. Vemos que a Igreja entende serem os jovens, vítimas, dentre tantas outras, das degradantes condições que desfiguram o homem em sua semelhança a Deus e posiciona-se veementemente pela vida, pelo respeito ao outro, tendo acima de tudo a vida do ser humano em Deus e os meios necessários para mantê-la dignamente. ${ }^{15}$ Junto aos jovens, Paulo VI via a esperança da Igreja, as possibilidades e os desafios de fazer acontecer os propósitos provenientes dos trabalhos conciliares. Neles se encontra a possibilidade de uma Igreja disposta a dar espaço para a dinamização do Espírito em meio à sociedade, permitindo o florescer de nova força para si e para toda humanidade. Já os documentos conciliares nos permitem compreender isso, quando deixam transparecer a grande preocupação com a educação das novas gerações, em vistas de uma formação integral que levasse em consideração também a experiência de Deus e dos valores cristãos, pelo bem de todos. ${ }^{16}$ Paulo VI nos diz:

A Igreja, durante quatro anos, tem estado a trabalhar para um rejuvenescimento do seu rosto, para melhor responder à intenção do seu fundador, o grande vivente, o Cristo eternamente jovem. E no termo desta importante "revisão de vida", volta-se para vós. É para vós, os jovens, especialmente para vós, que ela acaba de acender, pelo seu Concílio, uma luz: luz que iluminará o futuro, o vosso futuro. ${ }^{17}$

É verdade que o Concílio não dedicou um documento ou algum capítulo desses especificamente aos jovens, porém não deixou de tê-los como alvo de suas preocupações, uma vez que esteve em todos os momentos direcionado às necessidades do tempo presente, trabalhando para que a sociedade se tornasse cada vez mais comprometida com a dignidade e a liberdade das pessoas,

\footnotetext{
${ }^{13}$ GS 7.

${ }^{14}$ BINGEMER, M. C. L., El concilio y la emergência del laicado, p. 408.

${ }^{15}$ GS 27.

${ }^{16}$ GE 01.

${ }^{17}$ PAULO VI, PP., Mensagem aos jovens na conclusão do Concílio Vaticano II.
} 
inclusive dos próprios jovens, com fins a eterna salvação. Com o desejo de que a Igreja deixe espalhar-se o seu tesouro sempre antigo e sempre novo que é a fé, o Concílio empenhou-se para que os jovens também pudessem desfrutar de seus benefícios, experimentando a profunda alegria do evangelho, resistindo às tentações de ceder às filosofias do egoísmo e do prazer, ou do desespero e do nada, mantendo-se firme na fé em Deus que a tudo dá sentido. Lembramos que essa missão será possível às novas gerações na medida em que forem formados pelas precedentes, que por sua vez também formaram sua identidade cristã com base no testemunho de fé de toda a comunidade. ${ }^{18}$ Ainda na mensagem dirigida aos jovens após o Concílio, Paulo VI assim os exorta:

É em nome deste Deus e de seu Filho Jesus que vos exortamos a alargar os vossos corações a todo o mundo, a escutar o apelo dos vossos irmãos e a pôr corajosamente ao seu serviço as vossas energias juvenis. Lutai contra todo o egoísmo. Recusai dar livre curso aos instintos da violência e do ódio, que geram as guerras e o seu cortejo de misérias. Sede generosos, puros, respeitadores, sinceros. E construí com entusiasmo um mundo melhor que o dos vossos antepassados. ${ }^{19}$

Sua exortação nos permite compreender a profunda esperança que a Igreja pós-conciliar deposita nos jovens, e ao mesmo tempo o compromisso que tem com as novas gerações. Preocupa-se com as mais diversificadas dimensões de sua vida, desde a educação, como podemos ver de maneira bem detalhada na Declaração Gravissimum Educationis, a constituição de famílias que atuem positivamente na vida de seus filhos para que estes cresçam de forma digna, ${ }^{20}$ capacitados a sua escolha vocacional, ${ }^{21}$ com formação política, ${ }^{22}$ amparados em seu amadurecimento na fé, ${ }^{23}$ enfim, tendo garantidos seus direitos e sendo instruídos em seus deveres. ${ }^{24}$

Os documentos conciliares nos fazem compreender que as juventudes precisam ser iniciadas na fé, tomarem conhecimento das realidades do mundo e lerem nos sinais dos tempos o chamado do Senhor a serem anunciadores do evangelho e levarem adiante a boa nova de Jesus Cristo a todas as nações. ${ }^{25} \mathrm{~A}$

\footnotetext{
18 AG 41.

${ }^{19}$ PAULO VI, PP., Mensagem aos jovens na conclusão do Concílio Vaticano II.

${ }^{20}$ GS 49.

${ }^{21}$ GS 52.

${ }^{22}$ GS 75.

${ }^{23} \mathrm{PO} 6$.

${ }^{24}$ GS 27.

${ }^{25}$ AG 39.
} 
eles confia a missão de ser também povo de Deus, comprometidos com a evangelização em intensa responsabilidade testemunhal, ajudando-os a desenvolver zelo missionário diante de todos os povos ${ }^{26}$ e num caminho de mão dupla, receber a Igreja que vem ao seu encontro e ir ao encontro daqueles que não conhecem a Cristo. ${ }^{27} \mathrm{~A}$ Igreja pede às novas gerações, juntamente a adesão à fé por meios sacramentais e litúrgicos, que assumam a missão de empenhar suas vidas na construção de um mundo mais digno e justo para toda humanidade por meio de seu testemunho de união a Jesus Cristo. A Igreja confia a missão de anunciarem os valores evangélicos a todos os povos, permitindo que Cristo viva entre todas as nações, nas mais diversificadas culturas. ${ }^{28}$ A Igreja mostra aos jovens que sua missão é fazer com que na história o Reino tenha seu início, testemunhando no próprio viver a vida de Jesus Cristo, suas atitudes de misericórdia e compaixão diante das multidões famintas e abandonadas que vagam como ovelhas sem pastor (Mt 9,38), caminhando com a humanidade para a eternidade em Deus. Com o Concílio e, principalmente com a mensagem pós-conciliar dirigida aos jovens, temos certeza de que "a Igreja os olha com confiança e com amor", ${ }^{29}$ que ela aponta para Cristo como a verdadeira esperança dos jovens, que somente nele seu futuro terá um sentido repleto de alegria, que é Ele o "herói" verdadeiro capaz do amor, da verdade, da amizade, do companheirismo, da salvação.

Não podemos negar que essa esperança encarnada em meio à humanidade por vezes foi negligenciada em sua verdadeira identidade, o que contribui para que os jovens se afastem da Igreja, mesmo que não abandonem a fé em Deus. Assim, somos impelidos a revelar aos jovens "a verdadeira razão de sua esperança" ( $1 \mathrm{Pd} 3,15)$, aquele que os chama à verdadeira vida. Queremos, como bem afirmou Paulo VI, que os jovens ao olhar para a Igreja vejam "[...] o rosto de Cristo, o verdadeiro herói, humilde e sábio, o profeta da verdade e do amor, o companheiro e o amigo [...]". ${ }^{30}$ Parafraseamos o Concílio para afirmar que os jovens, em sua grande maioria pertencentes ao laicato, são aqueles que devem construir a cidade terrena, vivendo em meio ao mundo, chamados por Deus para exercer seu apostolado de modo a serem fermento levedando toda a massa. ${ }^{31} \mathrm{O}$ Concílio os convida a se identificarem plenamente a Jesus Cristo, contribuindo para glória de Deus em meio a humanidade.

\footnotetext{
${ }^{26}$ AG 20.

${ }^{27}$ AG 6.

${ }^{28}$ AG 21.

${ }^{29}$ PAULO VI, PP., Mensagem aos jovens na conclusão do Concílio Vaticano II.

${ }^{30}$ PAULO VI, PP., Mensagem aos jovens na conclusão do Concílio Vaticano II.

${ }^{31}$ AA 2.
} 
A constituição conciliar Gaudium et Spes nos fala da preocupação com os jovens que muitas vezes são alvos de valores contraditórios aos valores do Reino. Diz-nos que, "a transformação de mentalidade e de estruturas põe muitas vezes em questão os valores admitidos, sobretudo no caso dos jovens". ${ }^{32}$ Essa preocupação não quer condenar as novas gerações por sua vulnerabilidade diante do mundo, mas quer alertar a todos da necessidade que essas têm de serem olhadas atentamente, de forma a receberem das gerações anteriores o sustento para que também possam experimentar o verdadeiro encontro com Cristo e se tornarem testemunhas de seu amor, principalmente em meio a seus irmãos, também jovens. O Concílio sabe que "no seio da família, originam-se tensões, quer devido à pressão das condições demográficas, econômicas e sociais, quer pelas dificuldades que surgem entre as diferentes gerações [...]"33 e anseia por uma Igreja que esteja ao lado de tantas juventudes oprimidas e maltratadas por um sistema que desestrutura suas famílias e tantas outras instituições que podem colaborar de maneira efetiva na sã formação das novas gerações. Quando a Igreja afirma que, as alegrias e as esperanças, as tristezas e as angústias dos homens de hoje, são também as alegrias e as esperanças, as tristezas e as angústias dos discípulos de Cristo e que não há realidade humana que não encontre eco no seu coração, ${ }^{34}$ deixa-nos claro a sua intenção de estar ao lado de seus filhos e filhas, e aqui referimo-nos, especificamente, ao lado de seus filhos e filhas mais jovens, necessitados de verdadeiros testemunhos para seguir adiante como discípulos missionários de Cristo. O desejo conciliar de que a Igreja esteja unida à humanidade, principalmente aquela mais sofrida, não nos deixa duvidar de que ela esteja intimamente unida a todos os jovens que são sua esperança, e que ao mesmo tempo padecem pela falta da verdadeira esperança, ao verem diariamente perder-se seu presente, seus sonhos e seu futuro.

Certamente, como afirmou o Concílio, os jovens exercem na sociedade de hoje um influxo da maior importância, ${ }^{35}$ mas não podemos nos esquecer de que muitas das vezes são manipulados por essa mesma sociedade e tomados como fonte de exploração e lucro, atacados nos valores que alicerçaram inteiras gerações e destruídos em sua identidade mais íntima. Certamente é real a afirmação conciliar de que "as condições em que vivem, os hábitos mentais e

\footnotetext{
${ }^{32}$ GS 7.

${ }^{33}$ GS 7.

${ }^{34}$ GS 1.

${ }^{35}$ AA 12.
} 
até as relações com a própria família estão profundamente mudadas", ${ }^{36}$ mas entendemos com isso que se trata de uma resposta a tudo o que recebem dessa mesma sociedade, da forma como vêm sendo educados e inseridos no processo familiar, religioso e social. Não podemos apenas repetir chavões que os definam como uma massa única. Precisamos nos dar o direito de pensar suas realidades, sejam elas positivas ou negativas, mas sempre os tendo como parte do povo amado gratuitamente por Deus em suas situações de sofrimentos, e perenemente chamados a plena configuração com Cristo.

O Concílio nos dirá que os jovens precisam do testemunho dos adultos para poderem optar por Cristo e pela missão que lhes é confiada, colocando inclusive seus bispos e presbíteros como testemunhas necessárias e eficazes às novas gerações. ${ }^{37}$ Os pastores da Igreja são os primeiros e imediatos apóstolos das juventudes e ao exercerem seu apostolado entre eles, inseridos em suas realidades, levando em conta o meio em que vivem, ${ }^{38}$ estarão declarando sua esperança na capacidade de evangelização dos jovens e acreditando na força do Espírito Santo que move a humanidade na missão evangelizadora. Crer na força dos jovens é manifestar a compreensão de que também neles o Espírito age e permite experiências que geram novos testemunhos capazes de atingir tantos outros que também movidos pelo Espírito poderão fazer a experiência de Cristo. Não podemos prescindir da realidade de que esses dons necessitam ser suscitados no coração de nossos jovens e, por isso, mais uma vez queremos ressaltar as palavras conciliares que dizem que os adultos devem estabelecer com os jovens um diálogo amigo, superando a distância, favorecendo o conhecimento mútuo e a rica troca de experiências. Cabe aos adultos estimularem à juventude ao apostolado, e que o façam pelo testemunho e por palavras sábias. ${ }^{39}$ Tornar-se humano é um processo que ocorre entre seres humanos, tornar-se cristão é uma graça que nos é dada em meio à comunidade de fé, através daqueles e daquelas que já fizeram essa experiência. Se nossos jovens não forem agraciados com a práxis dessas belas palavras conciliares, possivelmente não trilharão os caminhos do evangelho, pois lhes serão desconhecidos. Do contrário, se forem iniciados na fé por meio de verdadeiros testemunhos, o Concílio irá encontrar ressonância nas novas gerações que não

\footnotetext{
${ }^{36}$ AA 12.

${ }^{37}$ GS 88.

${ }^{38}$ AA 12.

${ }^{39}$ AA 12.
} 
deixarão de mostrar "para com os mais velhos respeito e confiança e devida estima aquelas tradições que são válidas". ${ }^{40}$

Queremos adentrar nesse aspecto de integração entre as diferentes gerações, enfatizando a orientação conciliar, também registrada no Decreto Apostolicam Actuositatem, ao referir-se à formação dos leigos que estão inseridos na missão. Retomamos aqui a ideia de que a grande maioria dos jovens católicos pertencem ao laicato, e são eles os portadores da missão em meio às esperanças e angústias da sociedade. Portanto, é aceitável que, ao falar da formação laical, o Concílio também esteja falando da formação dos jovens que formam esse grupo. Compreender que "a preparação para o apostolado supõe uma formação humana completa e adaptada à maneira de ser e circunstâncias próprias de cada um [...]", ${ }^{41}$ nos faz crer que o Concílio estava aberto a acolher o jeito jovem de evangelizar e de ser evangelizado, com todas as suas belezas, bem como com todos os seus desafios. Quando vemos nos textos conciliares um registro como este: "com efeito, o leigo, conhecendo bem o mundo atual, deve ser um membro da sociedade em que vive e ao nível da sua cultura", ${ }^{42}$ entendemos que o Concílio esteja preocupado não apenas com o que este jovem leigo tem a oferecer para a Igreja, mas também com o que ele tem recebido da sociedade que é responsável por sua formação nos mais variados âmbitos e da consequente necessidade de ser edificado em Cristo.

Aprender a realizar a missão de Cristo pressupõe conhecer a Cristo intimamente, ter oportunidade de fazer a experiência do encontro a fim de tornar-se testemunho para os demais. Não podemos esperar que nossos jovens sejam fiéis testemunhas se lhes forem negados testemunhos que lhes abram à ação do Espírito e impulsione à experiência. Com o Concílio podemos afirmar que a inserção dos jovens nos horizontes da fé consiste em um aprendizado gradual e prudente, que passa pela convivência e não apenas por conteúdos teóricos e doutrinais. É algo que irá aperfeiçoar-se continuamente devido ao próprio processo de amadurecimento da pessoa. Esse processo exige que o jovem seja visto em todo o seu processo de desenvolvimento, para assim poder envolver-se ativamente na missão que Deus lhe confia no seio da Igreja, cuja ação desenvolve-se também em meio à sociedade. ${ }^{43} \mathrm{O}$ texto conciliar nos lembra de que essa formação para o apostolado deve ter seu início desde a tenra idade, sendo iniciados no apostolado particularmente os adolescentes e jovens.

\footnotetext{
${ }^{40}$ AA 12.

41 AA 29.

42 AA 29

43 AA 29.
} 
Dirá que tal formação deve ser aperfeiçoada por toda a vida e que pertence aos pais dispor os filhos para conhecerem o amor de Deus, e ensinar-lhes, principalmente pelo exemplo, o cuidado espiritual e material para com o próximo, sendo a família como que um estágio do apostolado. ${ }^{44}$

Essa educação proveniente das famílias e da comunidade de fé também possibilitará aos jovens a abertura para a comunidade eclesial e civil. Fazendo parte da comunidade irão reconhecer-se como membros ativos da mesma, verdadeiramente povo de Deus que traz consigo a missão de ir construindo o Reino de Deus na história, possibilitando uma vida mais digna não somente para si, mas para todos os irmãos que estão ao seu redor e até mesmo àqueles que pela distância e o tempo não lhes são conhecidos. Segundo o Concílio, essa formação para o apostolado também pode contar com a colaboração das instituições educacionais. Vemos no documento conciliar que cabe também às escolas e outras instituições católicas destinadas à formação, incentivar nos jovens o sentido católico e o apostolado. ${ }^{45}$ No curso da segunda sessão da realização do Concílio, em novembro de 1963, em meio ao debate eclesiológico, Y. Congar escreveu: "Cada geração tem sua tarefa. À nossa correspondeu à possibilidade de realizar na Igreja uma revolução pacífica decisiva. Os sobrinhos de nossos sobrinhos deverão renovar suas energias para permitir esta mudança tão importante". ${ }^{46}$ Como podemos ver é missão de cada geração a transmissão da fé, a formação daqueles que chegam e o testemunho convincente do encontro com Cristo. Parece-nos que se assim não procederem os adultos, dificilmente os jovens poderão assumir seus compromissos diante do Deus revelado por Jesus Cristo, pelo simples fato de não poderem reconhecer sua voz.

A esperança da Igreja nas juventudes lhe traz muitos desafios. Diante do novo que vem com os jovens a Igreja precisa agir como Mãe que acolhe seus filhos e filhas em suas próprias realidades, cuidando de todas as dimensões de suas vidas, para que a esperança que há em cada um não se apague e possa iluminar toda a sociedade. A Igreja Mãe não se aproxima de seus filhos e filhas para tirar vantagens, mas para amá-los e promover a vida, trabalhando pelo bem presente em vistas do futuro, da eternidade. Levar às novas gerações a revelação é um compromisso da Igreja de todos os tempos. ${ }^{47}$ Sabemos que Deus também veio ao encontro dos jovens, revelando-se em suas realidades, pois veio para os

\footnotetext{
${ }^{44}$ AA 30.

${ }^{45}$ AA 30.

${ }^{46}$ CONGAR, Y., Diario del Concilio, p. 135.

${ }^{47}$ DV 8.
} 
povos de todos os tempos, ${ }^{48}$ mas a ausência do testemunho será sempre um risco ao cristianismo. Aqui evocamos a Igreja desejada pelo Papa Francisco, uma Igreja Mãe e Pastora ${ }^{49}$ capaz de carregar nos braços cada um de seus filhos, de buscá-los nos lugares mais difíceis, a fim de resgatar-lhes a dignidade de criaturas amadas de Deus para então poder contar com seu testemunho evangélico em meio à vivência de tais valores no seio da sociedade. Também João Paulo II nos lembrará de que “[...] os jovens não devem ser considerados simplesmente como o objeto da solicitude pastoral da Igreja: são de fato e devem ser encorajados a ser sujeitos ativos, protagonistas da evangelização e artífices da renovação social". ${ }^{50}$ Vemos a necessidade de uma Igreja que ouse sair de seus templos, que não tenha medo de ser uma Igreja "acidentada", ${ }^{51}$ mas que se coloque em marcha com o povo, inclusive com as novas gerações, dando-lhes o direito de encontrá-la, pisando o chão de suas histórias pessoais e coletivas, reconhecendo em cada um o seu Senhor, Jesus Cristo, servindo-o e cuidando das chagas abertas nas tantas cruzes que carregam diariamente.

Nossa intenção não foi fazer uma profunda análise dos textos conciliares, mas em apontar para o fato de que direta ou indiretamente, o Concílio é direcionado também aos jovens, o que parece evidente nas palavras de Paulo VI, na mensagem pós-conciliar destinada a eles. Enfim, entendemos que o Concílio apresenta os jovens como esperança da Igreja ${ }^{52}$ preocupa-se com a evangelização das novas gerações e abre suas portas para acolhê-los e para colocar-se ao seu lado nas diversificadas realidades que enfrentam, de modo a poder anunciar-lhes Jesus Cristo. Vejamos na sequência como Francisco dá continuidade ao Vaticano II diante da temática juventude e esperança cristã.

\section{Em Francisco, as Juventudes como Esperança da Igreja e do Mundo}

Prosseguiremos nossa apresentação buscando nas palavras do Papa Francisco uma eclesiologia em continuidade com o Concílio Vaticano II, onde a esperança que a Igreja deposita nas juventudes manifesta-se em seu testemunho concreto. C. Kuzma aponta para uma renovação eclesial a partir de Francisco, uma renovação fundamentada no Concílio Vaticano II, que resgata a Igreja como mistério, isto porque nasce do Coração de Cristo, vem e recebe

\footnotetext{
${ }^{48}$ DV 7.

${ }^{49}$ SPADARO, A., "Procuremos ser uma Igreja que encontra caminhos novos".

${ }^{50}$ CFL 46.

${ }^{51}$ EG 49.

${ }^{52}$ GE 2; CD 14.
} 
sua missão de Deus e é conduzida pelo Espírito Santo, e como povo de Deus em comunhão com todos os batizados que no Cristo vivem seu ministério. ${ }^{53} \mathrm{Os}$ jovens são parte dessa Comunidade, neles está à esperança de uma Igreja em saída, de uma Igreja missionária, comprometida com todos, comprometida com o mundo e suas realidades, assim "somos todos chamados a esta nova saída missionária" ${ }^{54}$ Vemos neste pontificado, como no Concílio, o esforço por uma Igreja de portas abertas, capaz de iluminar os novos desafios, contando com a força de todos os batizados, fazendo com que ela seja a luz dos povos, Lumen Gentium.

A Igreja é chamada a sair, a estar em saída, a despojar-se do poder e revestir-se do serviço, a abraçar o Corpo sofredor de Cristo nos irmãos e irmãs que se encontram nas mais diferentes realidades de miséria. Essa é a Igreja que Francisco quer apresentar ao mundo, uma Igreja transbordante de misericórdia, cujo olhar assemelha-se ao de Deus, um olhar terno e compassivo para com os menos favorecidos, portadora de uma esperança ativa que vai ao encontro do outro para devolver-lhe a dignidade, dando ao mundo a vida em abundância em Cristo. Em Francisco reencontramos o apelo de estarmos nos novos areópagos, nas periferias do mundo, nas periferias da existência, eis que ele nos diz: "prefiro uma Igreja acidentada, ferida e enlameada por ter saído pelas estradas, a uma Igreja enferma pelo fechamento e a comodidade de se agarrar às próprias seguranças". ${ }^{55}$ É neste contexto de Igreja que nossas juventudes encontram seu espaço e sua valorização.

É num contexto de acolhida, compreensão e misericórdia que podem ser reconhecidos em suas realidades, sem julgamentos ou condenações, mas acolhidos na esperança, acolhidos na gratuidade, para serem formados em Cristo e impulsionados à missão da construção de um mundo mais justo para todos. É nesse contexto que ouvimos as palavras do Papa Francisco diretamente às juventudes no primeiro ano de seu pontificado, durante a Jornada Mundial da Juventude 2013. Ainda na viagem de vinda para o Brasil, o Papa, em entrevista, manifestou o desejo de encontrar com os jovens em suas realidades, na sociedade em que estão inseridos, revelando-nos a importância de vê-los a partir de todas as dimensões da existência e não de modo estanque em uma ou outra realidade. Ele nos diz que quer encontrar os jovens em suas realidades, não isolando-os ou fragmentando-os em sua real identidade: "[...] eu quereria encontrá-los precisamente no tecido social, em sociedade. Porque, quando

\footnotetext{
${ }^{53}$ KUZMA, C., Cantar com Francisco!, p. 205.

${ }^{54}$ EG 20.

${ }^{55}$ EG 49.
} 
isolamos os jovens, praticamos uma injustiça: despojamo-los da sua pertença. Os jovens têm uma pertença: pertença a uma família, a uma pátria, a uma cultura, a uma fé [...] e não devemos isolá-los!". ${ }^{56}$ Essa afirmação reconhece a multiplicidade de realidades nas quais estão inseridas as juventudes, reconhece a importância de abraçar os jovens em meio a tantas diversidades que the caracterizam, a não deixar de conhecer o chão em que pisam, visitando suas histórias, seus sonhos, seus medos, enfim, tudo o que são e aí sim o que poderão tornar-se. Francisco nos diz que esses jovens, com suas realidades são não apenas esperança e futuro da Igreja, mas que "eles são verdadeiramente o futuro de um povo". ${ }^{57}$ Entende que um povo vai adiante quando acolhe e investe em suas juventudes, pois deles vêm à força e a inovação que a sociedade necessita, e para isso merecem um olhar especial da Igreja, que como Mãe forma seus filhos e filhas em Cristo, dando-lhes a oportunidade de um discernimento sólido diante das tantas ofertas que o mundo lhes faz cotidianamente.

Francisco nos diz que Cristo "bota fe" nos jovens, que Cristo tem esperança nas juventudes, que lhes confia o futuro de sua própria causa. ${ }^{58} \mathrm{Cristo}$ pede aos jovens não apenas que sejam discípulos-missionários, mas que também façam discípulos. Cristo pede e espera que sejam verdadeiros discípulos na Igreja e na sociedade onde estão inseridos, que sejam verdadeiros agentes de transformação, que tenham a coragem e a ousadia de levarem adiante os valores cristãos, fazendo com que o Reino aconteça a cada dia até a sua plenitude. Apostar no jovem, apostar nas diversas juventudes, é acreditar no presente que eles significam e acreditar no futuro que chega por meio deles. Acolhê-los, revesti-los de dignidade, reconhecer seu potencial e seu agir em Cristo, é favorecer a chegada do futuro, é preparar um tempo de graça para toda a humanidade. Sim, as juventudes são as "janelas" por onde nos vem o futuro, porém é necessário entendermos, e Francisco nos ajuda nessa tarefa, pois se essas janelas estiverem "sujas e quebradas" a entrada do futuro estará comprometida. O Papa nos alerta para os cuidados que devemos manter com as juventudes, já que são a janela pela qual o futuro entra no mundo. As gerações que os precedem precisam aprender a abrir espaço para eles, ou seja, devem tutelar as condições materiais e imateriais para o seu pleno desenvolvimento, oferecer fundamentos sólidos, garantir segurança e educação, transmitir valores

${ }^{56}$ FRANCISCO, PP., Encontro com os jornalistas durante o voo para o Brasil, 22 de julho de 2013, p. 11.

${ }^{57}$ FRANCISCO, PP., Encontro com os jornalistas durante o voo para o Brasil, 22 de julho de 2013, p. 11.

${ }^{58}$ FRANCISCO, PP., Cerimônia de boas-vindas, discurso do santo padre Francisco, 22 de julho de 2013, p. 17. 
duradouros, assegurar um horizonte transcendente que responda à sede da verdadeira felicidade, despertar suas melhores potencialidades com vistas no seu futuro e de toda a humanidade. ${ }^{59}$

Sim, precedemos hoje o futuro que entra pela janela que são os jovens. Somos responsáveis por esses que constituem a esperança da Igreja e da sociedade. Somos responsáveis pelo presente que os abraça ou rechaça, somos responsáveis pelo melhor potencial desenvolvido ou pelas sombras que os sufocam e deságuam sobre a realidade social. Não podemos projetar um futuro maravilhoso entrando pelas janelas de nossas juventudes, se o presente estiver coberto de "sangue", de violências físicas, morais ou simbólicas, que tiram de tantas juventudes o direito de viver. Se a Igreja de fato quer que essas juventudes lhes sejam um futuro que, no presente antecipem o Reino, deve cuidar delas, deve desempenhar sua vocação materna de cuidar, de proteger, de ensinar a caminhar e incentivar passos de liberdade rumo à realização plena que é Cristo Crucificado Ressuscitado.

Transmitir aos jovens os valores que os ajudarão a construir um mundo mais justo é compromisso das gerações que os precedem. Para que isso aconteça Francisco exorta a Igreja e o mundo a conservar a esperança: "Nunca percamos a esperança! Nunca deixemos que ela se apague em nossos corações. [...] Deus é a nossa Esperança!". ${ }^{60}$ Mesmo que o poder da morte se apresente com força em meio à cultura do descartável que está tão forte na sociedade, a Deus pertence a "última palavra", Ele sempre vem ao encontro da humanidade e não deixa que o mal seja definitivo. Mesmo que ídolos queiram ocupar o lugar da verdadeira esperança, cabe aos adultos testemunharem que Deus permanece sempre fiel, nunca abandona seu povo, caminha lado a lado com a humanidade, fortalecendo a esperança da plenitude do Reino. Para tanto precisamos de cristãos capazes de serem "luzeiros de esperança", ${ }^{61}$ para que a esperança não se apague nos jovens corações e sejam sempre mais esperança para a Igreja e para o mundo. Homens e mulheres de esperança sabem e testemunham que Deus é fiel, ouve os clamores do povo, permanece ao lado dos pobres e humildes, e surpreende sempre. É Ele quem nos dá o "vinho da esperança", ${ }^{62}$

${ }^{59}$ FRANCISCO, PP., Cerimônia de boas-vindas, discurso do santo padre Francisco, 22 de julho de 2013, p. 19.

${ }^{60}$ FRANCISCO, PP., Santa missa na basílica do santuário nacional de nossa Senhora Aparecida, homília do santo padre, 24 de julho de 2013, p. 23.

${ }^{61}$ FRANCISCO, PP., Santa missa na basílica do santuário nacional de nossa Senhora Aparecida, homília do santo padre, 24 de julho de 2013, p. 24.

${ }^{62}$ FRANCISCO, PP., Santa missa na basílica do santuário nacional de nossa Senhora Aparecida, homília do santo padre, 24 de julho de 2013, p. 25. 
que não deixa que se apague as luzes da festa, pois ela ainda não está concluída, a melhor parte está por chegar, e Ele quer que a esperemos alegres, vivenciando tudo o que pudermos daquilo que aguarda ativamente sua completude. Esse testemunho pode alimentar a esperança das novas gerações, é para eles que a Igreja deve testemunhar a verdadeira esperança, pois, por meio deles, o Reino continuará entrando no mundo. Cristo é a fonte dessa esperança, sem Ele não há esperança, não há amor, não há futuro.

O Papa Francisco demonstra grande preocupação com as novas gerações. Não quer que percam a oportunidade de ter Cristo como sua verdadeira esperança, por isso exorta a Igreja a ser portadora desta esperança. Suas palavras são fortes, mas incentivam a caminhada daqueles que querem levar adiante a missão de Cristo em meio a humanidade, vejamos: "Não deixem que lhes roubem a esperança! Não deixem que lhes roubem a esperança! Mas digo também: Não roubemos a esperança, pelo contrário, tornemo-nos todos portadores de esperança!". ${ }^{63}$ Não roubar a esperança das juventudes, não as deixar à margem da Igreja, acolhê-las em suas realidades e deixá-las encontrar na Igreja a ternura divina, o espaço do amor e não da condenação, o espaço da acolhida afetuosa, da liberdade, do ensinamento, do crescimento, enfim, o espaço onde se sintam aceitos em suas realidades e tenham incentivos para alimentar seus sonhos e encontrar ânimo para dedicar-se à construção da verdadeira civilização do amor, partindo da edificação do homem interior em Cristo Jesus. O Papa nos lembra que saber acolher é muito mais importante que qualquer enfeite ou decoração, ${ }^{64}$ então acolher os jovens é um bom princípio de mútuo conhecimento, de espaço criado para que possam ficar e sentir-se Igreja. Essa acolhida exige despojamento da própria Igreja, inclusive de seus pastores, exige que se "tire as sandálias", pois estamos pisando em um lugar sagrado e muitas vezes desconhecido, onde Deus se faz presente, mas, exige também uma postura responsável que não se submete às mentiras que destroem a humanidade, o que faz com que a Igreja, ao lado das famílias, escolas e outras instituições responsáveis pela formação juvenil, ofereça aos jovens uma sólida formação alicerçada nas Escrituras, na Tradição, no Magistério e no testemunho de tantos santos e santas que encontraram a verdadeira felicidade em Cristo Jesus.

${ }^{63}$ FRANCISCO, PP., Palavras improvisadas do santo padre depois da missa na basílica de nossa Senhora Aparecida, 24 de julho de 2013, p. 32.

${ }^{64}$ FRANCISCO, PP., Visita a comunidade de Varginha, discurso do santo padre, 25 de julho de 2013, p. 38. 
A esperança do Papa Francisco nas juventudes está expressa também por suas expectativas diante dos jovens, eis o que nos diz o Pontífice: "[...] quero que se façam ouvir também nas dioceses, quero que saiam[...]. Quero que a Igreja saia às ruas, quero que nos defendamos de tudo que seja mundanismo, do que seja instalação, do que seja comodidade, do que seja clericalismo, do que seja estar fechados em nós mesmos". ${ }^{65}$ Vemos nas palavras do Pontífice a esperança de que com as novas gerações a Igreja viva sempre mais sua missionariedade, não permaneça apenas em suas estruturas mas, coloque-se a caminho, indo ao encontro de toda a humanidade. Uma Igreja em saída, uma Igreja sempre peregrina, uma Igreja que esteja em meio à humanidade para mostrar-lhe o rosto de Cristo, é isso que o santo padre espera das juventudes. Uma Igreja que, por experimentar e amar Cristo, o faz conhecido por todos os povos. Ele revela-nos essa belíssima face da Igreja que espera dos jovens o compromisso no anúncio de Jesus Cristo. Ele quer jovens que sejam jovens, que se façam ouvir, que tenham a ousadia dos jovens profetas, a ousadia do jovem de Nazaré que revolucionou a história da humanidade. Esperar que façam barulho, que não se calem, é acreditar que por meio de cada um deles(as) Deus irá surpreender a humanidade, não deixando que sua mensagem seja silenciada, mas fazendo-a audível e amada em meio a homens e mulheres, rapazes e moças de esperança. Para isso, "os jovens têm de sair, têm de se fazer valer [...]", ${ }^{66}$ precisam conhecer a dignidade de sua vocação, de serem cocriadores junto ao Criador, de serem sacerdotes, profetas e reis, pertencentes ao povo escolhido, capacitados pelo Espírito Santo para cumprir sua missão, e não simples receptáculos de ensinamentos.

Podemos dizer que a Igreja, por meio do Papa Francisco, espera que os jovens façam-se ouvir, que não peguem da fé apenas o que lhes convém, mas que tenham nas bem-aventuranças e em Mateus 25 seu programa de ação. ${ }^{67}$ Logo a esperança depositada nas juventudes fala de uma Igreja em saída, que a exemplo de Jesus, esteja em meio ao povo, dando-lhes de beber, de comer, vestindo-os, curando-os, visitando-os em suas mais diversificadas prisões. A Igreja deposita nos jovens a esperança que antecipa o Reino, a esperança que não aguarda o futuro para traduzir-se em vida, mas que no presente é o Reino do Senhor acontecendo, na viva esperança da eternidade. Espera que os jovens

${ }^{65}$ FRANCISCO, PP., Encontro com os jovens argentinos na catedral de são Sebastião, palavras do santo padre Francisco, 25 de julho de 2013, p. 44.

${ }^{66}$ FRANCISCO, PP., Encontro com os jovens argentinos na catedral de são Sebastião, palavras do santo padre Francisco, 25 de julho de 2013, p. 45.

${ }^{67}$ FRANCISCO, PP., Encontro com os jovens argentinos na catedral de são Sebastião, palavras do santo padre Francisco, 25 de julho de 2013, p. 46. 
revelem a beleza do rosto jovem de Cristo ao mundo, do Cristo vivo que habita em cada um, do Cristo que faz crescer neles as asas da esperança,${ }^{68}$ faz crescer a liberdade dos filhos e filhas de Deus para que caminhem na direção daquele que é a verdadeira esperança. Em Francisco a Igreja encoraja as juventudes a persistir no caminho, e diz: “'Ponha Cristo' em sua vida e encontrará um amigo em quem confiar sempre; 'ponha Cristo' e verá crescer as asas da esperança para percorrer com alegria o caminho do futuro; 'ponha Cristo' e sua vida estará repleta de seu amor, será uma vida fecunda". ${ }^{69}$

A Igreja deposita nos jovens a esperança de cristãos maduros na fé, que alimentados pela verdadeira esperança possam ser esperança para todos, que repletos de vida sejam fecundidade de vida para a humanidade, que encontrem em Cristo os fundamentos para a própria existência, que tenham viva a convicção de que Jesus os espera e conta com cada um. Francisco lembra a Igreja que os jovens são esperança do povo, "os jovens porque carregam a força, o sonho, a esperança do futuro", ${ }^{70}$ se assim são reconhecidos diante do povo, não pode ser diferente diante da Igreja que é o povo de Deus. As afirmações do Papa desinstalam, fazem com que os pastores da Igreja e seus agentes pastorais saiam ao encontro do futuro, não se fechem a ele, isto é, saiam ao encontro das juventudes, estejam abertos ao novo que com os jovens pode nascer na Igreja, não se acomodem diante de seus sofrimentos e desesperanças, pois eles são Igreja de Jesus Cristo, são o rosto jovem de Cristo a trilhar novos rumos onde a Igreja de hoje precisa estar presente se quiser cumprir o mandato de Jesus de ir por todos os lugares anunciando o evangelho e promovendo a vida a cada criatura. O Papa insiste em afirmar que Cristo continua precisando dos jovens para sua Igreja, que não tenham medo do protagonismo, da ousadia, que: "Chutem para frente, construam um mundo melhor. Um mundo de irmãos, um mundo de justiça, de amor, de paz, de fraternidade, de solidariedade. Joguem para frente. [...] Na Igreja de Jesus, as pedras vivas somos nós, e Jesus nos pede que edifiquemos sua Igreja [...]". ${ }^{71}$ Nas palavras do Pontífice vemos a esperança de que outros jovens, assim como o de Assis, se disponham a reparar a Igreja de Jesus Cristo, a renová-la sempre nos fundamentos evangélicos. O Papa sabe

${ }^{68}$ FRANCISCO, PP., Festa de acolhida dos jovens, saudação e homilia do santo padre, 25 de julho de 2013, p. 49-55.

${ }^{69}$ FRANCISCO, PP., Festa de acolhida dos jovens, saudação e homilia do santo padre, 25 de julho de 2013, p. 55.

${ }^{70}$ FRANCISCO, PP., Encontro com o episcopado brasileiro, discurso do santo padre, 27 de julho de 2013, p. 86.

${ }^{71}$ FRANCISCO, PP., Vigília de oração como os jovens, discurso do santo padre Francisco, 27 de julho de 2013, p. 117. 
que o coração das juventudes almeja um mundo melhor, sabe que querem ser protagonistas de mudança, que buscam uma civilização mais justa e fraterna. $\mathrm{O}$ santo Padre assim se expressa:

O coração de vocês, coração jovem, quer construir um mundo melhor. Acompanho as notícias do mundo e vejo que tantos jovens, em muitas partes do mundo, saíram pelas ruas para expressar o desejo de uma civilização mais justa e fraterna. Os jovens na rua. São jovens que querem ser protagonistas da mudança. Por favor, não deixem que outros sejam os protagonistas da mudança. Vocês são os que têm o futuro. Vocês [...]. Por vocês entra o futuro no mundo. [...] Continuem superando a apatia e oferecendo uma resposta cristã às inquietações sociais e políticas que vão se levantando em diversas partes do mundo. Peço-lhes que sejam construtores do futuro, que se metam no trabalho por um mundo melhor. $^{72}$

Não cessa de confirmar a esperança da Igreja e da sociedade nas juventudes, não cessa de dizer-lhes o quanto acredita em cada um, e incentivaos a percorrer os caminhos de Jesus Cristo em meio à humanidade, fazendo com que o Reino vá acontecendo até o dia de sua plenitude. O Pontífice sabe que as juventudes são "os atletas de Cristo", os construtores de uma Igreja mais bela e de um mundo melhor. ${ }^{73}$ Para que os jovens possam viver essa missão que Cristo lhes confia, faz-se necessário que a "Igreja adulta" esteja ao seu lado, lhes ofereça "seu coração, seu abraço, sua escuta, seu testemunho, sua orientação", enfim, seja verdadeira Mãe e Pastora, para que seus filhos e filhas reconheçam a voz do Senhor que chama e não se deixem vencer pelo medo de dar-lhe seu "sim". O Papa pede: "Por favor, continuem acompanhando-os com generosidade e alegria, ajudem-lhes a se comprometer ativamente na Igreja; que nunca se sintam sós". ${ }^{74}$ Em seus discursos, Francisco exorta a Igreja a ser testemunha de esperança para as novas gerações. Ele sabe que essa esperança que a Igreja deposita nos jovens não se concretizará se esses mesmos jovens não forem alimentados na esperança, se não forem abraçados pelo testemunho daqueles que desempenham o serviço de pastores de um povo. Exorta a Igreja a não perder sua esperança, a não deixar de acreditar que Deus vem por meio

${ }^{72}$ FRANCISCO, PP., Vigília de oração como os jovens, discurso do santo padre Francisco, 27 de julho de 2013, p. 118-119.

${ }^{73}$ FRANCISCO, PP., Vigília de oração como os jovens, discurso do santo padre Francisco, 27 de julho de 2013, p. 119.

${ }^{74}$ FRANCISCO, PP., Santa missa para a $28^{\mathrm{a}}$ jornada mundial da juventude, homilia do santo padre, 28 de julho de 2013, p. 125. 
de suas juventudes, que são eles que recebem a herança da fé e a passarão adiante, não deixando que se apague no mundo a "luz que é Cristo", não deixando que os valores evangélicos sejam suprimidos pela cultura de morte que ronda a humanidade. Vemos que desde o início de seu pontificado, Francisco demonstra grande preocupação com os jovens, com suas realidades atuais e com o futuro de cada um. Não por acaso lança para a Igreja um Sínodo que posiciona os jovens no centro das preocupações eclesiais.

\section{Conclusão}

Com esta breve pesquisa podemos perceber que a Igreja tem profundo e verdadeiro interesse pelos jovens. Entende serem eles sua esperança não apenas para o futuro, mas também para o presente. No entanto, não podemos nos limitar a olhar apenas para a esperança que a Igreja deposita nos jovens. Precisamos compreender que à Igreja cabe a missão de levar aos jovens a verdadeira esperança, capaz de dar a vida das mais diversas juventudes o verdadeiro sentido de sua própria existência, isto é, Jesus Cristo, a Esperança Cristã.

Vemos que o Concílio demonstrou grande interesse nas realidades juvenis e suas necessidades. Não podemos nos limitar ao fato de não encontrarmos um documento específico que trate do tema juventude, mas numa pesquisa mais aferida, poderemos ver que os jovens estão sim inclusos nos documentos conciliares, uma vez que esses demonstram grande preocupação com todo o povo de Deus, e de maneira especial por aqueles que mais sofrem e são vulneráveis em sua dignidade. $\mathrm{O}$ faz ao tratar do compromisso que tem seus pastores e todos os cristãos adultos diante da herança da fé a ser entregue às novas gerações, ao cuidar da qualidade da educação oferecida pelas famílias, escolas e demais instituições católicas, ao reportar-se a missão que os leigos tem em meio a sociedade, ao demonstrar preocupação com todos os sofrimentos que atingem a humanidade, e em tantas outras ocasiões, a Igreja conciliar fazse próxima e companheira das juventudes de todos os tempos.

Com Francisco é nítida a confiança que a Igreja deposita nos jovens e a preocupação que tem com seu presente e seu futuro. Não podemos compreender, no atual pontificado, uma Igreja distante das realidades juvenis, seus desafios e esperanças. Cabe a Igreja oferecer às novas gerações a oportunidade de crescer na fé por meio de uma verdadeira experiência de Cristo. O pontífice incentiva os jovens a prosseguirem, com entusiasmo e ousadia, nos caminhos de Jesus, a levarem adiante a Boa Nova e buscarem 
antecipar na terra o Reino que será definitivo em Deus. Com a proposta do tema "Os jovens, a fé e o discernimento vocacional", Francisco coloca no centro da Igreja as juventudes e pede que todos se dediquem a suscitar nos jovens corações o verdadeiro desejo do encontro com o Ressuscitado, que traz a luz necessária para que cada um prossiga em seu caminho, dizendo como a Virgem de Nazaré seu Fiat a vontade divina, que é a plena realização do homem, da mulher, de todos os tempos.

\section{Referências bibliográficas}

ABRAMO, H. W. Retratos juvenis. In: ABRAMO, H. W.; BRANCO, P. P. M. (Orgs.). Retratos da Juventude Brasileira: análises de uma pesquisa nacional. Rio de Janeiro: Fundação Perseu Abramo, 2005. p. 44.

BÍBLIA de Jerusalém. Nova ed. rev. e ampl. 2. impr. São Paulo: Paulus, 2003. BINGEMER, M. C. L. El concilio y la emergência del laicado. Revista Internacional de Teologia Concilium, n. 346, p. 103-114, jun. 2012.

BINGEMER, M. C. L. Vaticano II uma referência do nosso tempo. Disponível em: $<$ http://amaivos.uol.com.br/amaivos09/noticia/noticia.asp?cod_Canal=47\&cod_notici $\mathrm{a}=20975>$. Acesso em: 04 set. 2018.

CONCÍLIO ECUMÊNICO VATICANO II. Declaração Gravissimum Educationis, 28 de outubro de 1965. In: COMPÊNDIO DO VATICANO II. Constituições, Decretos, Declarações. 29. ed. Petrópolis: Vozes, 2000. n. $1500-1532$.

CONCÍLIO ECUMÊNICO VATICANO II. Constituição Dogmática Dei Verbum, 18 de novembro de 1965. In: COMPÊNDIO DO VATICANO II. Constituições, Decretos, Declarações. 29. ed. Petrópolis: Vozes, 2000. n. 161-199.

CONCÍLIO ECUMÊNICO VATICANO II. Decreto Apostolicam Actuositatem, 18 de novembro de 1965. In: COMPÊNDIO DO VATICANO II. Constituições, Decretos, Declarações. 29. ed. Petrópolis: Vozes, 2000. n. 1331-1459.

CONCÍLIO ECUMÊNICO VATICANO II. Constituição Dogmática Gaudium et Spes, 07 de dezembro 1965. In: COMPÊNDIO DO VATICANO II. Constituições, Decretos, Declarações. 29. ed. Petrópolis: Vozes, 2000. n. 200-520. 
CONCÍLIO ECUMÊNICO VATICANO II. Decreto Ad Gentes, 07 de dezembro de 1965. In: COMPÊNDIO DO VATICANO II. Constituições, Decretos, Declarações. 29. ed. Petrópolis: Vozes, 2000. n. 862-1013.

CONGAR, Y. Diario del Concilio: segunda sessión. Barcelona: Estela, 1964.

CELAM. Civilización del amor: proyecto y misión. Bogotá: CELAM, 2012. (Doc. 173).

CELAM. Conclusões da conferência de Puebla: evangelização no presente e no futuro da América Latina. 13. ed. São Paulo: Paulinas, 2004.

ESTEVES, L. C. G.; ABRAMOVAY, M. Juventude, juventudes: pelos outros e por ela mesma. In: ABRAMOVAY, M.; ANDRADE, E. R.; ESTEVES, L. C. G. (Orgs.). Juventudes: outros olhares sobre a diversidade. Brasília: MEC / UNESCO, 2007. p. 19-54.

FRANCISCO, PP. Cerimônia de boas-vindas, discurso do santo padre Francisco, 22 de julho de 2013. In: FRANCISCO, PP. Palavras do Papa Francisco no Brasil. São Paulo: Paulinas, 2013. p. 15-19.

FRANCISCO, PP. Encontro com o episcopado brasileiro, discurso do santo padre, 27 de julho de 2013. In: FRANCISCO, PP. Palavras do Papa Francisco no Brasil. São Paulo: Paulinas, 2013. p. 85-108.

FRANCISCO, PP. Encontro com os jovens argentinos na catedral de são Sebastião, palavras do santo padre Francisco, 25 de julho de 2013. In: FRANCISCO, PP. Palavras do Papa Francisco no Brasil. São Paulo: Paulinas, 2013. p. 43-48.

FRANCISCO, PP. Encontro com os jornalistas durante o voo para o Brasil, 22 de julho de 2013. In: FRANCISCO, PP. Palavras do Papa Francisco no Brasil. São Paulo: Paulinas, 2013. p. 7-14.

FRANCISCO, PP. Exortação Apostólica Evangelli Gaudium sobre o anúncio do evangelho no mundo atual. São Paulo: Paulinas, 2013.

FRANCISCO, PP. Festa de acolhida dos jovens, saudação e homilia do santo padre, 25 de julho de 2013. In: FRANCISCO, PP. Palavras do Papa Francisco no Brasil. São Paulo: Paulinas, 2013. p. 49-58.

FRANCISCO, PP. Palavras improvisadas do santo padre depois da missa na basílica de nossa Senhora Aparecida, 24 de julho de 2013. In: FRANCISCO, PP. Palavras do Papa Francisco no Brasil. São Paulo: Paulinas, 2013. p. 27-28. 
FRANCISCO, PP. Santa missa na basílica do santuário nacional de nossa Senhora Aparecida, homília do santo padre, 24 de julho de 2013. In: FRANCISCO, PP. Palavras do Papa Francisco no Brasil. São Paulo: Paulinas, 2013. p. 21-26.

FRANCISCO, PP. Santa missa para a $28^{\mathrm{a}}$ jornada mundial da juventude, homilia do santo padre, 28 de julho de 2013. In: FRANCISCO, PP. Palavras do Papa Francisco no Brasil. São Paulo: Paulinas, 2013. p. 121-126.

FRANCISCO, PP. Vigília de oração como os jovens, discurso do santo padre Francisco, 27 de julho de 2013. In: FRANCISCO, PP. Palavras do Papa Francisco no Brasil. São Paulo: Paulinas, 2013. p. 111-120.

FRANCISCO, PP. Visita a comunidade de Varginha, discurso do santo padre, 25 de julho de 2013. In: FRANCISCO, PP. Palavras do Papa Francisco no Brasil. São Paulo: Paulinas, 2013. p. 37-42.

GONÇALVES, H. S., Juventude brasileira, entre a tradição e a modernidade. Tempo Social, v. 17, n. 2, p. 207-219, jul./dez. 2005.

JOÃO PAULO II, PP. Exortação Apostólica Pós-Sinodal Christifideles Laici. 9. ed. São Paulo: Paulinas, 1999.

KUZMA, C. Cantar com Francisco! Provocações eclesiológicas a partir da Evangelii Gaudium. In: AMADO, J. P., FERNANDES, L. A. (Orgs.). Evangelii Gaudium em questão: aspectos bíblicos, teológicos e pastorais. Rio de Janeiro: Editora PUC-Rio / Paulinas, 2014. p. 195-208.

PAULO VI, PP. Mensagem aos jovens na conclusão do Concílio Vaticano II. Disponível em:

$<$ http://www.vatican.va/holy_father/paul_vi/speeches/1965/documents/hf_pi_spe_19651208_epilogo-concilio-giovani_po.html>. Acesso em: 03 set. 2018.

PAULO VI, PP. Carta Encíclica Populorum Progressio, 26 de março de 1967. Disponível em:

$<$ http://www.vatican.va/holy_father/paul_vi/encyclicals/documents/hf_pvi_en c_26031967_populorum_po.html>. Acesso em: 03 set. 2018.

SINGER, P. A Juventude como coorte: uma geração em tempos de crise social. In: ABRAMO, H. W.; BRANCO, P. P. M. (Orgs.). Retratos da Juventude Brasileira: análises de uma pesquisa nacional. Rio de Janeiro: Fundação Perseu Abramo, 2005. p. 27-35. 
SPADARO, A. "Procuremos ser uma Igreja que encontra caminhos novos". Entrevista com Papa Francisco. Disponível em: $<\mathrm{http}$ //www.ihu.unisinos.br/n oticias/523920-procuremos-ser-uma-igrejaque-encontra-caminhos-novos-entrevista-com-o-Papa-francisco $>$. Acesso em: 09 set. 2018.

Gislene Danielski

Doutoranda em Teologia pela Pontifícia Universidade Católica do Rio de Janeiro Rio de Janeiro / RJ - Brasil E-mail: gislenedanielskifdz@gmail.com

Recebido em: $13 / 09 / 18$ Aprovado em: 26/11/18 